\title{
THE FIRST GONGRESSIONAL ELECTION IN NEW JERSEY
}

\author{
By George P. Schmidt
}

$\mathrm{E}$

VERYONE even slightly familiar with New Jersey history knows that the state elected a Congressional delegation in 1789 which was friendly to the new Constitution; but the political cross-currents and the local issues which determined the outcome of this first election are not so well known. A letter recently acquired by the library from the correspondence of Joseph Bloomfield and Jonathan Dayton gives us a glimpse of what went on behind the scenes. ${ }^{1}$ Written by Bloomfield on Feb. 28, I789, while the election was in progress, it tells a story of intense personal conflicts and high pressure politics which proves that Jerseymen even at that early date had little to learn of the fine art of politics.

An intelligent reading of the letter, with its allusions to tickets, polls, and campaign methods, is possible only if one fully understands the election practices of the time. These were based on two fundamental laws. The first, passed in $1783,{ }^{2}$ laid down the rules for all state elections, and the second, in $1788,{ }^{3}$ was designed to fit the new federal elections into the existing framework. It was thus provided that the four members of the National House of Representatives to which New Jersey was entitled were to be elected on the second Wednesday in February from a statewide list of nominees. Any inhabitant, aged 2I and "worth Fifty Pounds Proclamation Money," might hand a signed ticket of four names to his county clerk, but no later than thirty days before the election. All the nominations were sent to the governor who was instructed to assemble and

1 The letter is printed in full on pp. $48-50$.

Joseph Bloomfield, I753-1823, born in Woodbridge, later lived in Burlington. He was the first Republican governor of New Jersey, I80I-I8I 2 .

Jonathan Dayton, I760-I824, of Elizabeth, though defeated in the first Congressional election, was elected four times after that, eventually serving as Speaker. Then he moved to the Senate, in 1799. He was a speculator in western lands and a friend of Aaron Burr.

${ }^{2}$ Acts of the Eightb General Assembly of the State of New Fersey. Ch. XI. Dec. I6, I783.

${ }^{3}$ Acts of the Twelfth General Assembly of the State of New Fersey. Ch. CCXLI. Nov. $21,1788$. 
publish the total list in "The News-Papers printed in this State and in two or more printed in the cities of New York and Philadelphia," at least eighteen days before the election. The sheriffs were then to post this official list at five places in each county. In the matter of time and place of voting the law allowed much latitude. In some counties written ballots were required while in others viva voce voting was prescribed. While in general, elections were to be held at the place of quarter sessions, various exceptions were permitted; the Burlington poll, for example, might be shifted to Bordentown, and in Essex the election might be adjourned "to the house where Jeremiah Smith lives in Elizabeth-town." No closing hour was fixed, but election officers were empowered to close the polls whenever they thought all voters had had "a reasonable time" to appear. They could also adjourn the poll from day to day. Such wide powers were open to abuse as the Bloomfield letter clearly shows. To secure honest voting the law forbade bribery by "fee, reward, victuals, drink or entertainment."

In accordance with the rules thus established the first Congressional election got under way. The state legislature had already chosen the two senators and the six presidential electors ${ }^{4}$ when Governor William Livingston announced the list of nominees. ${ }^{5}$ There were fifty-three all told, of whom seven-Bloomfield being one-declined to serve. The voting, though it was to begin on the second Wednesday in February, was not completed for some time. Both our letter and contemporary newspaper items indicate that election judges in several counties took full advantage of their authority to shift and postpone, and it was not until March I9 that the governor was able to announce the final results. ${ }^{6}$

${ }^{4}$ On the first Wednesday in January. Ibid.

5 The proclamation and the complete list are in the New Fersey Fournal and Political Intelligencer of Elizabeth town for Jan. 21, 1789 .

${ }_{6}$ The Pennsylvania Packet and Daily Advertiser carried an item indicating that the four junto candidates were leading in Burlington (Mar. 13). An Elizabeth dispatch in the same paper (Mar. I6) stated: "The poll of this county is adjourned until Wednesday the I8th inst. at Elizabeth-Town. It may safely be conjectured, that this measure is adopted in consequence of the manoeuvres of the five western counties in delaying their returns beyond the time prescribed by law in order to profit by a knowledge of the returns from the eight counties in the east." The same paper declared (Mar. 23) that the four junto candidates appeared to be elected, and announced (Mar. 30) the governor's official proclamation of the Igth to the same effect. Even then the returns from one county (probably Essex) were missing. 
Looking at the election through Bloomfield's eyes, we see two organized slates of candidates. The first group, the jun to ticket to whose campaign practices Bloomfield raised such strenuous objections, was made up of Elias Boudinot, Lambert Cadwallader, James Schureman (Rutgers, I775), and Thomas Sinnickson. ${ }^{7}$ Loosely linked in opposition to these four were Jonathan Dayton, the recipient of Bloomfield's letter, and his friend Abraham Clark. ${ }^{8}$ A sentence near the end of the letter suggests that perhaps John Witherspoon, signer of the Declaration and president of the College of New Jersey, and Alexander McWhorter, patriotic pastor of the Presbyterian Church of Newark, were bracketed with Dayton and Clark.

To see in these two groups the birth of the Hamiltonian and the Jeffersonian party would be to take unwarranted liberties with the evidence. For all eight, and Bloomfield too, belonged to the landed class and to the business and professional groups, which had managed the affairs of the state since the Revolution. All, with the possible exception of Clark, were considered Federalists, i.e., supporters of the Constitution. It is true that Bloomfield slowly drifted into the Jeffersonian ranks and became the first Republican Governor of New Jersey, but this was not apparent in 1789 . The divisions in this first election grew out of personal, geographic, and religious differences, and did not represent any definite party alignments. Presbyterians and Quakers were the two most numerous political bodies, and the strength of the junto faction was evidently in the Quakercontrolled counties of West Jersey, while the Dayton-Clark ticket had its principal support among the Presbyterians of the northeastern counties.

The junto appears in the letter as a close-knit, well-organized faction. They had secured the endorsement of the State As-

${ }^{7}$ James Schureman, I756-r824, of New Brunswick, had served in the Revolution as had most of the other candidates. After several terms in Congress he became mayor of New Brunswick. Elias Boudinot, I740-I821, of Elizabeth, well-known as a president of the Continental Congress, a strong supporter of Hamilton's financial measures in the House of Representatives, was later a director of the mint. Lambert Cadwallader, 1743-1823, of Trenton, served in the Revolution, the Continental Congress, and two terms in the House of Representatives. Thomas Sinnickson, $1744^{-18} 81$, of Salem, a merchant, also served in the war and was later one of the Adams and Pinckney electors.

${ }^{8}$ Abraham Clark, I 726-1 794, of Elizabeth, signer of the Declaration, was a farmer, opposed to lawyers, and the only one of the prominent candidates who was considered lukewarm toward the Constitution. 
sembly; their ticket was printed (there was no official ballot in those days); they evidently controlled the election machinery, at any rate in the southwestern counties, if Bloomfield was correctly informed. To the politically lethargic Quakers they pictured the horrors of a nation in the hands of the ScotchIrish Presbyterians who, allied with the New England radicals, would legalize paper money (apparently in the face of the prohibition in the new Constitution) and might even plunge the country in to war again. Their representations were successful; in spite of the best efforts of Bloomfield and his friends, the entire junto ticket was swept in to office. The first Congressmen from New Jersey were, accordingly, James Schureman, I 2,537 votes, Lambert Cadwallader, 8,685, Elias Boudinot, 8,603, and Thomas Sinnickson, $8,203 .{ }^{\circ}$ Dayton, high man on the Bloomfield ticket, just failed to nose out Sinnickson.

Dear Sir,

Burlington, Feb: 28th: 1789 . Late Saturday Evening.

In my letter of last Evening (wh I sent by Stage, under cover to Sam Smith) I give a State of the Burlington Poll \& measures pursued to carry the junto-Ticket. I will mention the substance of that Letter.

Norcross, Hollinshead and myself went to the election at Moores-Town, on our way through Mount-Holly, we sollicited the company of Ross \& Cox, and who followed on, but we could do little or nothing in that quarter, Rd. S. Smith, who keeps a Store in Moore[s]-Town \& of great influence, having taken unweried pains to support the junto-Ticket \& prejudice the People against $\mathrm{M}^{\mathrm{r}}$. Clark \& Yourself. There was a meeting of Col. Ellis, and two other leading characters from Gloucester at R. S. Smith's and the Burlington Gentry Danl. Ellis, Joshua M. Wallace, Danl. Newbold, \&c: \&c. in consequence of Cummings \& Jona. Rheas visit on that day, into the Western Counties. Maj. Howell of Trenton was with them.

After this, we could get no intelligence of the number of votes taken. It was given out that the Poll probably would be closed at Burlington, when at same time there was a fixed determination to travel the second time to Kellum's (called cross-Keys in Evesham) and to the New-Mills. By what I can learn their Generalissimo Col. Ellis, prescribed 2500 at least, and if possible more, could they be obtained in Burlington-then returned with his chosen Friends to Haddonfield (only 8 miles off) where the Gloucester Election was then Polling to co-operate with the Burlington Election at Moores-Town. Thus their measures have been concerted to support their junto-favorite-Ticket, originally the Embryo of Col. Ellis and which $\mathrm{He}$ is determined shall be brought forth into Life. There was about 2295 votes

${ }^{9}$ The Pennsylvania Packet for Mar. 24 gives these figures. 
in the Box when the Poll adjourned last Evening from Burlington to Kellum's Cross-Keys.

Soon as Austin arrived I had a meeting with Norcross \& Hollinshead, both unwell with colds taken in their late return from Moore's-Town Thursday night - after consultation. I dispatched one of my Clerks to Woodbury and Hollinshead (though very unwell) set out for Mt. Holly to wait Ross's return from Kellum's (Cross-Keys). It is now after eleven at night. Hollinshead has returned, and says, Ross informed him that about 100 or 120 votes He supposed was taken, that the Clerks pretend they have not lately numbered the votes $\&$ therefore cannot take the trouble to count them. (The Clerks are Rd. R. Smith, cozen of Rd. S. Smith a son of John Lawrence \& a son of D. Ellis) the inspectors all of the same Class, one of them Tom Hewlings, who returned but very lately from Nova Scotia.

Ross finding that the Tickets $\mathrm{He}$ give out, were generally changed by those who watched for this purpose, and no confidence to be placed in any man. He sent up for Volunteers among the Workmen of Taunton IronWorks, and in Martial parrade led up 25 with the Proprietor Hastings and who voted immediately from Ross's hand, to the no small vexation \& mortification of the Inspectors \& Junto-solid-compact. But all this I fear has a tendency to rouse and excite our opponents to greater opposition and industry in turning out every one without exception - and indeed, the Blind, lame, sick \& even decrepid old age, is not suffered to be at their desired ease, at home.

In order to induce the rigid Quaquers to turn out, who heretofore said "They did not feel a Freedom to vote" the advocates for the junto-ticket, have raised another Story, truly ridiculous indeed-Yet, serves the purpose for which it is propagated, among the uninformed weak part of this Society. "Come Friend, go to the Election and vote for the Ticket recommended by the Assembly, vote for the Federal-Ticket, the West-Jersey-Ticket, the Quaquers Ticket, recommended by Friends,-Come, turn out, oppose the Prysbeterian Ticket. The Prysbeterions want another War, they want another opportunity to distrain Your goods for pretended Militia-duty." The Peaceable Quaquer, says, "No, I don't feel a Freedom, Thee must excuse me, I never intend to interfere in Government-matters, it is against my Principles."

"You don't feel a Freedom, You will loose Your freedom, Your Liberty and Your Property, nay more, Your Religion, if You do not; we Church People see very clearly these Presbyters want to rule, and, then, there will be no other Religion suffered in this Country, but Presbyterianism, the most arbitrary and tyrannic of all Religions. But, Dayton \& Clarke are bloody men, are men for War, they want another War, that they may make their fortunes by distress from the Quaquers, and, if they get into Congress, they will join with the New-England-Congress Men and we shall have War \& Blood-shed immediately- the Gentlemen in our West-Jersey-Ticket, are good peaceable Men, they will oppose all War-measures. Congress will be brought to Phila, may be to Burlington and the Markets will then be good, we shall have no Paper Money. Clarke \& Dayton was the means of 
making the present Paper trash, they had it made to pay their Debts, particularly Clarke, I can shew You this in Print \& Certified by Your Friends the Shottwells of Rhaway, who have been cheated by this Clarke. But War is their present scheme, particularly Dayton, who with his Father and all his Presbyterian Family of the Ogdons, have shed a great deal of Blood, they all thirst for Blood again, nay, Dayton \& Clarke, after having War a while, will, if they can, hang all the Quaquers as they formerly did in NewEngland and as poor Carlile was during the late War in Phila in 1778. Elias Boudinot, altho' then a Congress-Man, Pleaded for Carlile and wanted to save his Life, but Presbyterian Joe Reed, then Governor had him hanged because $\mathrm{He}$ was a Quaquer, and pardoned all the Presbyterians, who were condemned to be hanged also, for the same charge as against Your Friend Carlile, who was a member of Your meeting \& often visited at Burlington at Your quarterly meetings. Lambert Cadwalladers Brother wrote a piece against Joe Reed for this conduct, now Your Friends Elias Boudinot \& Lambert Cadwallader are in this Ticket, and also, James Schureman, who last Fall got the Law passed to free the Poor Negroes, who have all voted for him, as to Sinnickson the last name in this printed Ticket, You know He lives in Salem \& that all his Family connections are Friends, these are the honest, good men You ought to vote for. But, if You want War and to be persecuted by the Presbyterians, stay at home, \& see who will pity You when Your goods are distrained and Your Meeting-Houses are made barracks as here to fore, for Soldiers \& Men of War." Much more such stuff is dealt out to the poor Quaquer, particularly, that two Scotch Presbyterian Hirelings are joined in the Ticket of Clarke \& Dayton, meaning Witherspoon \& McWhorter. Upon this, the Wife, Mother, and all the Family, cry out "go, go, go to the Election and vote for the Printed-Ticket." \&c. \&c. The Poor Friend being alarmed at the situation of his Society, finds "Freedom" takes the Printed junto-Ticket, \& away He goes, with such of his Neighbours as He can influence by telling them the same melancholy taleto keep out the blood-thirsty Presbyterians and to prevent War, Blood \& Slaughter.

In Continuation, Sunday I/2 after Eleven A.M. I: March 1789 .

My Clerk John White is this moment returned. Enclosed is Mr. Hunters Letter which contains no more than what I have already written to You. I suppose from the best information I can procure that there will be from 25 , to 26,00 votes taken in Burlington.

My Clerk tells me that the Gloucester Election was held Yesterday at the Tavern near Pensaukin Bridge, within 200 Yards of this County \& about 6 miles from Coopers Ferry a Place not mentioned in the ElectionLaws \& which I take to be illegal.

Let me hear from You by Post, send me Your last Eliz. Town Papers for a month back. Remember me to Mrs. Dayton \& all Friends. In haste. $\mathrm{Y}^{\mathrm{r}}$ sincerely,

Joseph Bloomfield. 